\title{
The Effects of Infusion of Insulinlike Growth Factor (IGF) I, IGF-II, and Insulin on Glucose and Protein Metabolism in Fasted Lambs
}

\author{
R. G. Douglas, P. D. Gluckman, K. Ball, B. Breier, and J. H. F. Shaw \\ Departments of Surgery and Paediatrics, University of Auckland, Auckland, New Zealand
}

\begin{abstract}
In vivo effects of 300-min infusions of recombinant insulinlike growth factor I (IGF-I) and IGF-II on glucose and protein metabolism have been investigated in awake, fasted lambs. Two doses of recombinant human (rh) IGF-I were infused: $6.7 \mathrm{nmol} /$ $\mathrm{kg} \cdot \mathrm{h}$, which induced hypoglycemia, and $2.0 \mathrm{nmol} / \mathrm{kg} \cdot \mathrm{h}$, which did not. The effects were compared with an insulin infusion $(0.17 \mathrm{nmol} / \mathrm{kg} \cdot \mathrm{h})$ that had the same hypoglycemic potential as the high dose rhIGF-I infusion. rhIGF-II was infused at a rate of $6.7 \mathrm{nmol} / \mathrm{kg} \cdot \mathrm{h}$. Primed constant infusions of isotopically labeled glucose, urea and leucine tracers were used to determine glucose and protein kinetics. rhIGF-I lowered blood glucose by increasing the rate of glucose clearance $(P<0.01)$, in contrast to insulin, which both increased clearance and reduced glucose production. Net protein loss was reduced after infusion of low and high dose rhIGF-I and insulin by $11 \%(P<0.05)$, $15 \%(P<0.01)$, and $12 \%(P<0.05)$, respectively. rhIGF-II infusion did not alter the rate of net protein loss. In contrast to insulin, high dose rhIGF-I infusion increased the rate of protein synthesis in skeletal $(P<0.05)$ and cardiac muscle $(P<0.01)$ and in hepatic tissue $(P<0.05)$.

We conclude that $(a)$ protein metabolism is more sensitive than glucose metabolism to rhIGF-I infusion, as protein loss was reduced by an rhIGF-I infusion that did not alter glucose kinetics; (b) protein synthesis is increased by rhIGF-I infusion but not by insulin infusion; and (c) rhIGF-II is a less effective anabolic agent than rhIGF-I. We speculate that the effects of rhIGF-I on protein metabolism are not mediated by insulin receptors. (J. Clin. Invest. 1991. 88:614-622.) Key words: insulin• IGF-1 • IGF-2 • protein synthesis • catabolism
\end{abstract}

\section{Introduction}

As insulin-like growth factors I and II (IGF-I and IGF-II) ${ }^{1}$ share considerable structural homology with insulin (1), it is not sur-

This work was presented in part at the 72nd Annual Meeting of the Endocrine Society, Atlanta, GA, 1990 (Abstract 1142) and was supported by grants from the Medical Research Council of New Zealand.

Address correspondence to Dr. P. D. Gluckman, Developmental Physiology Laboratory, Department of Paediatrics, University of Auckland, Private Bag, Auckland, New Zealand.

Received for publication 25 September 1990 and in revised form 11 February 1991.

1. Abbreviations used in this paper: FSR, fractional rate of synthesis; IGF-I and -II, insulin-like growth factors I and II; NPL, net protein loss; $\mathrm{Ra}$, rate of appearance; rh, recombinant human; SA, specific activity.

J. Clin. Invest.

(c) The American Society for Clinical Investigation, Inc.

0021-9738/91/08/0614/09 \$2.00

Volume 88, August 1991, 614-622 prising that the three hormones have qualitative similarities in their biological actions $(2,3)$. IGF-I and -II have been observed in vitro to increase glucose uptake and to possess antilipolytic activity in cell cultures (4), but with a molar potency that is considerably less than that of insulin $(5,6)$. These findings have been reproduced in vivo during IGF-I and -II and insulin infusions in rats (7) and after the administration of IGF-I and insulin bolus injections to human subjects (8). However, the IGFs have been reported to possess considerably more mitogenic and growth-promoting activity than insulin in in vitro preparations (9), and to be more effective in accelerating protein synthesis and reducing protein breakdown in L6 myotube cultures (10). IGF-I has the ability to restore growth in hypophysectomized $(11,12)$ and diabetic rats (13). Recently it has been reported that acute IGF-I infusions reduce the rate of whole body protein catabolism in normal adult rats (14). It has been suggested that while growth may be primarily mediated by the paracrine production of IGF in tissues, circulating IGF may play a role in coordinating the anabolic state of the organism (15). IGF-II appears to have some growth promoting potential in hypophysectomized rats, but to be a less potent anabolic agent than IGF-I $(16,17)$. The ability of the three hormones to interact with each other's receptors and tissue differences in receptor distribution may account for many of the similarities in their biological effects. It has been suggested that whereas the actions of IGF-I on glucose metabolism are mediated by insulin receptors, stimulation of growth by IGF-I is mediated by IGF receptors (18).

In contrast to insulin, virtually all IGF is noncovalently bound to several distinct forms of specific carrier proteins (19, $20)$. The IGF binding proteins greatly extend the plasma halflife of these hormones (21) and may serve a reservoir function, ensuring that small amounts of IGFs are constantly available to the tissues. Recently, it has been demonstrated that a reduction in plasma binding protein concentration increases the efflux of IGF-I from the plasma compartment to the tissues, demonstrating that binding proteins can influence the availability of IGF-I to the tissues (22). While the binding proteins appear to inhibit some IGF-I actions (23) so that only free IGF-I and -II appear to have hypoglycemic activity (7), there is evidence from in vitro studies that the association of IGF-I with plasma binding protein may enhance mitogenic activity $(24,25)$.

There are several studies that report improvement in the nitrogen balance of severely septic or injured patients following the administration of human growth hormone (26-28). As IGF-I may mediate the anabolic effects of growth hormone, IGF-I may possess some clinical potential in the nutritional support of such critically ill patients who typically have an accelerated rate of protein catabolism and who may have some degree of growth hormone resistance (29). We have therefore undertaken a study of the effects on protein and glucose metabolism of a short-term infusion of pharmacological doses of rhIGF-I. The effects of this infusion were compared to a molar equivalent dose of recombinant human (rh)IGF-II and to an 
insulin infusion of equivalent hypoglycemic potential. A lower dose of rhIGF-I that did not induce hypoglycemia was infused in order to attempt to determine whether there was a difference in the sensitivity of carbohydrate and protein metabolism to IGF-I. These observations have been reported in preliminary form (30).

\section{Methods}

The studies were performed using cryptorchid crossbred lambs of average weight $16 \mathrm{~kg}$ and age range 3-5 mo. The animals were housed indoors for at least a week before being studied, and during this time they were accustomed to slings in which they were restrained during the performance of the experiments. The animals were fasted for $48 \mathrm{~h}$ to reduce the interference of protein absorbed from the gut on the measurement of endogenous protein turnover. On the morning of the study the animals were weighed and placed in Pavlov slings. A dose of diazepam $(0.3 \mathrm{mg} / \mathrm{kg}$ i.m. $)$ was then administered and Surflo teflon catheters (Terumo Australia Ltd., Melbourne, Australia) inserted into the external jugular veins. A 20-gauge catheter was inserted caudally into one external jugular vein to enable infusion of isotopes and hormones, and a 16-gauge catheter was inserted rostrally into the contralateral vein to facilitate the taking of blood specimens. The catheters were attached to three way taps via Portex manometer tubing (Portex Ltd., Hythe, UK) and the isotopes and test solutions were infused through this system by Vial Medical pumps (Vial Médical, Grenoble, France).

The experimental protocol is illustrated in Fig. 1. The priming dose for the isotopic infusions was administered at $0900 \mathrm{~h}$, and during the first $180 \mathrm{~min}$ normal saline and isotopes were infused simultaneously while isotopic equilibrium was being reached. At the end of this period, blood specimens were collected to enable a baseline measurement of substrate turnovers. After this the test infusions were begun and continued over a 300 -min period, during which time plasma specimens were taken at 60 -min intervals. At the end of the test infusions, the animals were killed by intravenous injection of $5 \mathrm{~g}$ phenobarbitone and tissue samples of liver, heart, diaphragm, and psoas and hind limb adductor muscle were taken as rapidly as possible, washed in cold normal saline, blotted dry, and rapidly frozen in liquid nitrogen. All blood specimens were collected in chilled, heparinized tubes and were immediately centrifuged, and the separated plasma was frozen before being analyzed.

\section{Hormone infusions}

The animals were infused during the test period with one of five solutions: normal saline at a rate of $10 \mathrm{ml} / \mathrm{h}(n=6)$, rhIGF-I at a dose of 2.0 $\mathrm{nmol} / \mathrm{kg} \cdot \mathrm{h}(n=4)$, or $6.7 \mathrm{nmol} / \mathrm{kg} \cdot \mathrm{h}(n=6)$, rhIGF-II at a dose of 6.7 $\mathrm{nmol} / \mathrm{kg} \cdot \mathrm{h}(n=4)$, or recombinant human insulin at a dose of 0.17 $\mathrm{nmol} / \mathrm{kg} \cdot \mathrm{h}(n=4)$. The insulin dose was empirically chosen after preliminary experiments to result in the same percentage reduction in the plasma glucose concentration as the high dose $(6.7 \mathrm{nmol} / \mathrm{kg} \cdot \mathrm{h})$ IGF-I infusion. This represents an rhIGF-I/insulin molar ratio of 40:1. The low $(2.0 \mathrm{nmol} / \mathrm{kg} \cdot \mathrm{h})$ dose rhIGF-I was selected because although it resulted in a doubling of the baseline plasma IGF-I concentration, it

\begin{tabular}{c}
\hline Isotopes: $:^{15} \mathrm{~N}$ urea, ${ }^{14} \mathrm{C}$ leucine, \\
$6^{3} \mathrm{H}$ glucose \\
\hline
\end{tabular}

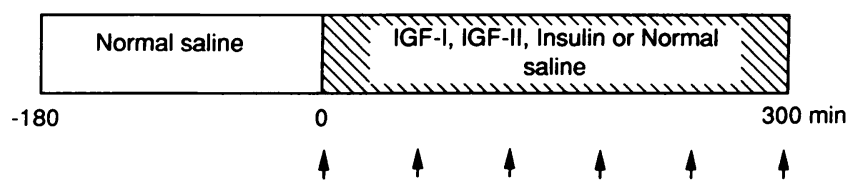

Figure 1. The experimental protocol. Plasma specimens were taken at 60 -min intervals between 0 and $300 \mathrm{~min}$. did not significantly alter glucose kinetics. The rhIGF-I was donated by Kabi Peptide Hormones (Stockholm, Sweden) and the rhIGF-II by Elanco (Greenfield, IL). The recombinant human insulin was obtained from Eli Lilly (Fegersheim, France). Immediately before infusion, all of the hormones were dissolved in $55 \mathrm{ml}$ normal saline, and $0.5 \mathrm{ml}$ of the plasma from the animal to be infused was added to reduce hormone binding to the surface of the syringe and plastic tubing. The hormone/ normal saline solutions were infused at a rate of $10 \mathrm{ml} / \mathrm{h}$.

\section{Isotopic infusions}

The rates of turnover of metabolic substrates were measured by the technique of primed constant infusion of stable and radioactively labeled tracers. The rate of appearance $\left(R_{a}\right)$ of glucose was measured by 6 ${ }^{3} \mathrm{H}$-glucose infusion of $7.5 \mathrm{nCi} / \mathrm{kg} \cdot \min$ after an $80: 1$ prime (31). The prime/infusion ratios were based on ratios previously established in studies in dogs and normal volunteers, and isotopic equilibrium was confirmed by specific activity measurements over the last $60 \mathrm{~min}$ of the baseline period. The rate of appearance $\left(R_{a}\right)$ of urea was determined by a primed constant infusion of ${ }^{15} \mathrm{~N}$ urea (rate $10 \mu \mathrm{g} / \mathrm{kg} \cdot \min$ and 450:1 prime) and whole body leucine kinetics were quantified by a primed constant infusion of ${ }^{14} \mathrm{C}$ leucine at a rate of $7.5 \mathrm{nCi} / \mathrm{kg} \cdot \min$ after a $60: 1$ leucine prime (31). The $R_{a}$ of urea enabled calculation of the net rate of protein loss (see Calculations), and the $R_{a}$ of leucine was used as an indicator of the rate of total protein breakdown and subsequent amino acid release from the tissues. The protein fractional synthetic rates of the various tissues sampled were calculated from the rate of change of tissue ${ }^{14} \mathrm{C}$ leucine specific activity (see Calculations).

The radio-isotopes were obtained from Amersham Laboratories (Buckinghamshire, UK) and the ${ }^{15} \mathrm{~N}$ urea from Isotechnique.

\section{Sample analysis}

The plasma enrichment of ${ }^{15} \mathrm{~N}$ urea was determined by first deproteinizing the plasma sample by addition of sulphosalicylic acid (31). The supernatant was then passed over a column of Dowex $50 \mathrm{~W} \times 8100$ 200 mesh hydrogen ion resin (Sigma Chemical Co., St. Louis, MO). The urea was washed from the column by rinsing with $2 \mathrm{~N} \mathrm{NH}_{4} \mathrm{OH}$. The eluate was then dried and the atom percent excess was determined by an isotope ratio mass spectrometer.

The HPLC method of Nissen et al. was used in a modified form to determine the concentration of leucine in 1-ml plasma samples (32). The specific activity of leucine in the plasma was determined by first passing the plasma over Dowex 50-W hydrogen ion exchange resin (Sigma Chemical Co.) and washing the branch chain amino acids from the column with $4 \mathrm{~N} \mathrm{NH}_{4} \mathrm{OH}$. The amino acids were then incubated with amino acid oxidase and catalase enzymes. The solutions were then back extracted and samples were injected into a high pressure liquid chromatograph, and 100- $\mu$ l aliquots of the isolated branch chain amino acids were added to a scintillant solution (ACS II, Amersham Australia Ltd., Sydney, Australia) and counted on a Rack Beta scintillation counter (LKB Wallac, Turku, Finland), and hence the specific activity of leucine was derived. Tissue specimens were defatted with ether, freeze dried, then hydrolyzed for $24 \mathrm{~h}$ in $\mathrm{HCl}$ at $110^{\circ} \mathrm{C}$. The hydrolyzed specimens were then centrifuged, diluted, and processed as for plasma.

Plasma glucose specific activity was determined by first precipitating the plasma proteins with $\mathrm{Ba}(\mathrm{OH})_{2}$ and $\mathrm{ZnSO}_{4}$ solutions (33). The eluate was evaporated to dryness, and reconstituted in $1 \mathrm{ml}$ of distilled water. The glucose concentration of the reconstituted eluate was measured by an Hitachi 704 Autoanalyser (Hitachi, Tokyo, Japan), and $0.5-\mathrm{ml}$ samples of the remainder were pipetted into glass scintillation vials and counted in $10 \mathrm{ml}$ of ACS II scintillant (Amersham).

The plasma concentrations of glucose, urea, sodium, and potassium were measured by an Hitachi 704 Autoanalyser.

\section{Plasma hormone concentrations}

IGF-I. Plasma IGF-I was measured by RIA using a rabbit antiserum to rh-metIGF-I (878/4) at a final titer of 1:150,000 (34). The antiserum has a cross-reaction with IGF-II of $<0.1 \%$, a minimal detectable dose 
of $0.06 \mathrm{ng} /$ tube, and a half displacement dose of $0.40 \mathrm{ng} /$ tube. Before immunoassay, plasma samples were subject to acid-ethanol extraction with an additional cryo-precipitation step. This extraction and assay have been extensively validated for sheep plasma (34). For example, the correlation between values for sheep plasma obtained using this extraction technique and those of Sephadex G75 chromatography in 1 $\mathrm{M}$ formic acid was $r=0.98(P<0.001, n=10)$ and the slope of the linear regression was 1.02. Using this extraction system, the interassay coefficient of variation was $9.8 \%$ and the within assay coefficient of variation was $5.0 \%$ (34).

Measurement of circulating molecular forms of IGF-I. The circulating molecular forms of IGF-I in plasma were measured using a modifcation of the method of Butler and Gluckman (35). In brief, aliquots of $500 \mu \mathrm{l}$ were subjected to high-performance gel chromatography on a Superose 12 column $(10 \times 300 \mathrm{~mm}$, Pharmacia Fine Chemicals, Uppsala, Sweden) fitted to a Pharmacia Fast Protein Liquid Chromatography System calibrated as described previously (36). The column was equilibrated with $0.1 \mathrm{~mol}$ phosphate/liter buffer containing $0.15 \mathrm{~mol}$ $\mathrm{NaCl} /$ liter and $0.02 \% \mathrm{NaN}_{3}$ (pH 7.2), and the samples were eluted with the same buffer at a flow rate of $0.5 \mathrm{ml} / \mathrm{min}$. Fractions of $0.25 \mathrm{ml}$ were collected after an 8-min delay into silicone-coated tubes containing 20 $\mu l$ of $1 \%$ BSA (wt/vol) in water. The fractions containing free IGF-I eluted at fractions 49-60. IGF-I associated with binding proteins of $35-60 \mathrm{kD}$ eluted at fractions 39-48, and IGF-I associated with binding proteins of 120-160 kD eluted at fractions 29-38. These three groups of fractions were pooled and aliquots were subjected to acid-ethanol and cryo-precipitation extraction before RIA. The immunoreactive IGF-I eluting in the second pool is termed " $35-60 \mathrm{kD}$ " IGF-I and represents IGF-I bound to IGF binding protein-I and other low molecular weight binding proteins. The IGF-I eluting in the third pool is termed for convenience " $150 \mathrm{kDa}$ " IGF-I and is primarily IGF-I associated with the IGF binding protein- 3 and its acid labile subunit. Recoveries of unlabeled $\gamma$-rhIGF-I added to the plasma before high-performance gel chromatography, extraction, and RIA were in the order of $95-110 \%$. Complete linearity was found in the range of 0-500 ng rhIGF-I added per milliliter plasma. In pilot experiments, after ${ }^{125}$ I IGF-I administration in vivo (37) we found no alteration in the distribution of ${ }^{125}$ I IGF-I across the three pools when chromatographed immediately after sampling or after $24 \mathrm{~h}$ at $4^{\circ} \mathrm{C}$ or after a single freeze/ thaw cycle.

Insulin. Plasma insulin was measured by RIA using a guinea pig antiserum to ovine insulin at a final titer of $1: 400,000$. The assay has a minimal detectable dose of $0.15 \mathrm{ng} /$ tube and a half displacement dose of $0.40 \mathrm{ng} /$ tube. The incubation mixture consisted of $100 \mu \mathrm{l}$ of standard or test plasma and $200 \mu \mathrm{l}$ of assay buffer containing ovine insulin antiserum. After preincubation at room temperature for $24 \mathrm{~h}$, ${ }^{125}$ I-labeled insulin $(15,000 \mathrm{cpm})$ was added in $200 \mu \mathrm{l}$ of assay buffer and the incubation was continued for $18-24 \mathrm{~h}$ at $4^{\circ} \mathrm{C}$. Bound and free insulin were separated by addition of $1 \mathrm{ml}$ of a second antibody complex containing 4\% polyethylene glycol 6000 made up in $0.01 \mathrm{M}$ PBS. The test tubes were then incubated for $1 \mathrm{~h}$ at room temperature and centrifuged at $3,000 \mathrm{~g}$ for $30 \mathrm{~min}$ at $4^{\circ} \mathrm{C}$. The supernatant was decanted and the radioactivity in the remaining pellet was determined. The interassay coefficient of variation was $11.5 \%$ and the within assay coefficient of variation was $6.7 \%$.

\section{Calculations}

The rates of appearance of urea, leucine, and glucose were calculated using either the Steele equation or a modification of the Steele equation applicable to stable isotopic tracers $(30,38)$. For the radioactive tracers, $R_{a}=f / S A$, where $f$ is the rate of infusion of isotope (decays $/ \mathrm{min} /$ $\mathrm{kg} \cdot \mathrm{min}$ ) and $S A$ is specific activity (decays $/ \mathrm{min} / \mu \mathrm{mol}$ ). For ${ }^{15} \mathrm{~N}$ urea, $R_{a}=(99 / A P E-1) \times f$, where $A P E$ is atom percent excess and $f$ is the rate of infusion of isotope $(\mu \mathrm{mol} / \mathrm{kg} \cdot \mathrm{min})$.

The net rate of protein loss ( $\mathrm{g}$ protein $/ \mathrm{kg} \cdot$ day) was calculated from the $R_{a}$ of urea by multiplication by a constant $(0.252)$, a factor derived from the number of millimoles of nitrogen in a gram of protein (31). The fractional synthesis rate of protein of tissues per $24 \mathrm{~h}$ was given by the equation: [Change of tissue $S A$ leucine $\times 1,440 \times 100 /\left(t_{1}-t_{0}\right)$ ]/ [Change of plasma $S A$ leucine]

The change in tissue leucine specific activity $(S A)$, in units of decays per minute per micromole leucine was calculated assuming that the ${ }^{14} \mathrm{C}$ $S A$ of all tissues was zero at the beginning of the ${ }^{14} \mathrm{C}$-leucine infusion. The time of the beginning of the isotopic infusion was recorded as $t_{0}$ (minutes) and $t_{1}$ was the time at which the animal was killed and tissue was removed. For the measurements of protein fractional synthetic rate (FSR) performed in this study, the plasma leucine specific activity was assumed to reflect that of the precursor pool for protein synthesis. Although it has been demonstrated that the calculated protein synthetic rate may vary depending on whether the estimates are based on intracellular (tissue homogenate) or plasma-specific radioactivity (39), the index we used provides a valid measurement of the rate of uptake of leucine from the plasma to the tissues. This is analogous to determining the rate of release of leucine from the tissues by measuring the rate of appearance of leucine into the plasma compartment. However, our methodology would underestimate changes to the FSR of tissues as a result of the hormone infusion. This is because during the initial 180 min of ${ }^{14} \mathrm{C}$ leucine infusion (before the beginning of hormone infusion), the tissues incorporated labeled leucine at the basal rate, which would then act to dilute the effect of any change in the rate of tracer uptake over the subsequent 300 -min hormonal infusion.

\section{Statistics}

Dunnett's test was applied to repeated measures taken over the duration of the infusions. Similarly, Dunnett's variation of one-way factorial analysis of variance (ANOVA) was used to compare the tissue rates of fractional synthesis of the hormone treated with those of normal saline-infused controls. The data are expressed as means \pm SEM.

\section{Results}

\section{Plasma hormone concentrations}

The low and high dose rhIGF-I infusions increased the plasma IGF-I concentration above baseline by two- and fivefold, respectively, whereas infusion of rhIGF-II reduced the plasma IGF-I concentration by almost half (Fig. 2). The plasma concentration of IGF-I did not change significantly during the insulin infusion.

The distribution of IGF-I between binding-protein bound (35-60 kD and $150 \mathrm{kD}$ ) and free $(7 \mathrm{kD})$ forms was determined

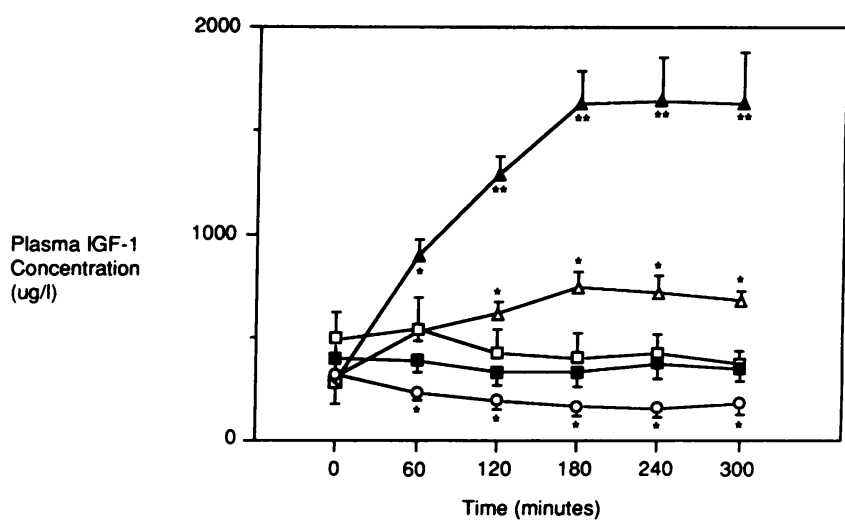

Figure 2. Plasma IGF-I concentrations during hormone infusions. rhIGF-I caused a dose-related increase in plasma IGF-I levels, whereas IGF-II infusion halved the plasma IGF-I concentration. rhIGF-I 2.0 $\mathrm{nmol} / \mathrm{kg} \cdot \mathrm{h}(\Delta)$, rhIGF-I $6.7 \mathrm{nmol} / \mathrm{kg} \cdot \mathrm{h}(\Delta)$, rhIGF-II $6.7 \mathrm{nmol} / \mathrm{kg} \cdot \mathrm{h}$ $(0)$, insulin $0.17 \mathrm{nmol} / \mathrm{kg} \cdot \mathrm{h}(\boldsymbol{(})$, and normal saline (ם) infusion. $\left(^{*}\right)$ $P<0.05,\left(^{* *}\right) P .<0.005$ compared with $0 \mathrm{~min}$, all data are means \pm SEM. 

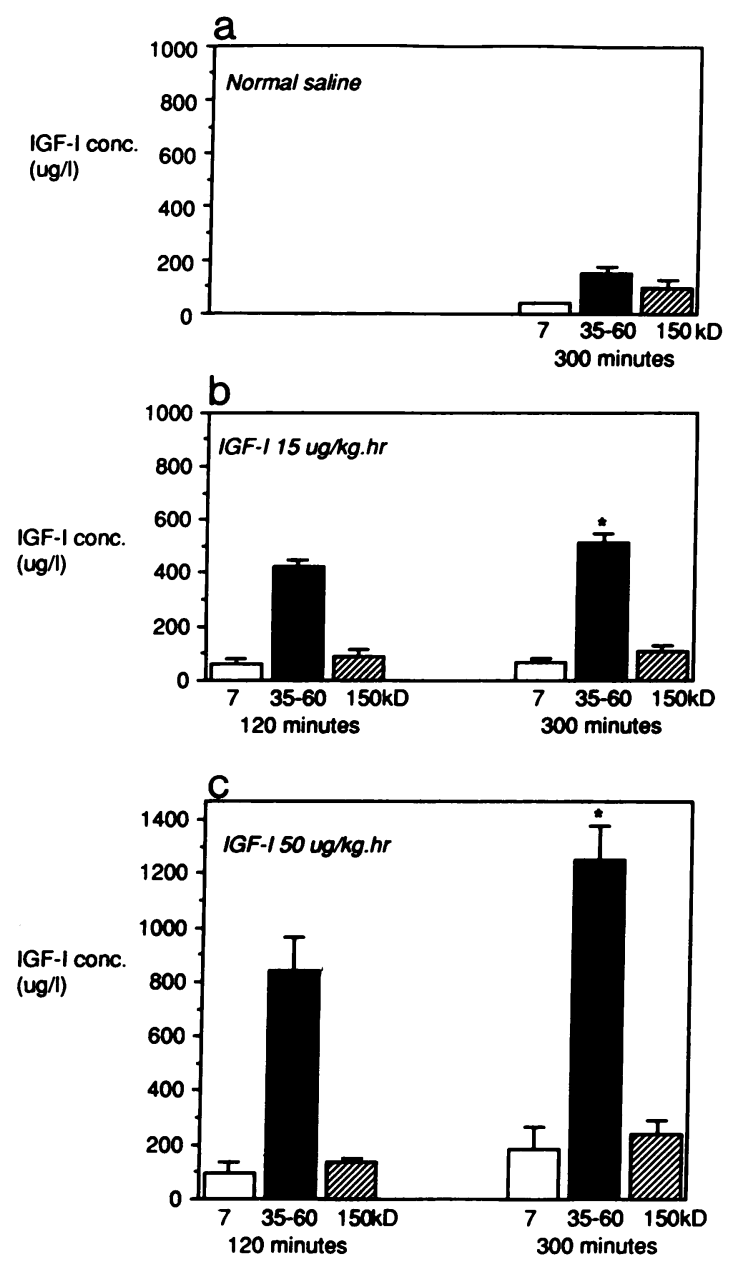

Figure 3. $(a-c)$ The distribution of IGF-I across the IGF binding proteins. The 7-kD fraction represents free IGF-I and the 35-60- and $150-\mathrm{kD}$ forms are IGF associated with low and high molecular weight binding proteins. The concentration of free IGF-I in the normal saline-infused animals was below the minimum detectable dose of the RIA ( $<40 \mu \mathrm{g} /$ liter). $\left(^{*}\right) P<0.05$ compared with normal saline-infused controls.

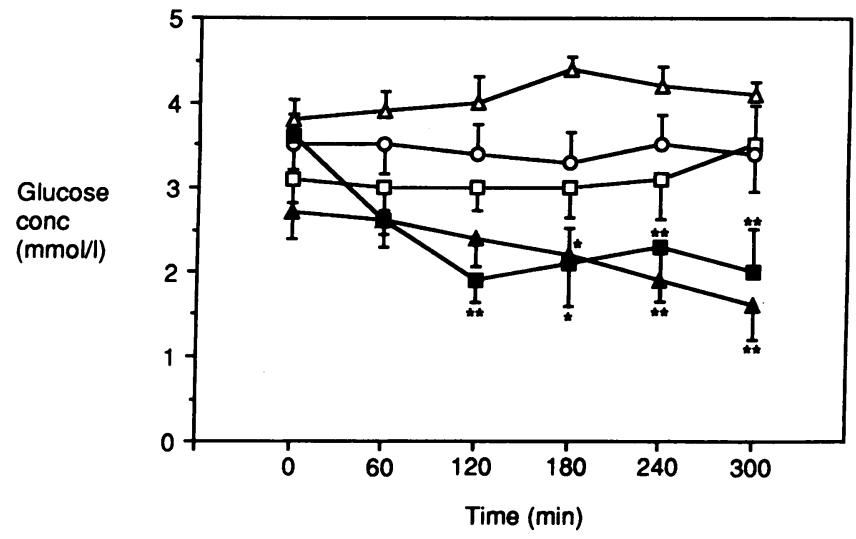

Figure 4. Effect of rhIGF-I $2.0 \mathrm{nmol} / \mathrm{kg} \cdot \mathrm{h}(\Delta)$, rhIGF-I $6.7 \mathrm{nmol} /$

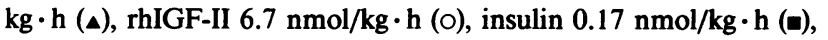
and normal saline ( $\square$ ) infusion on glucose concentration. $\left({ }^{*}\right) P<0.05$, $\left.{ }^{(* *}\right) P<0.01$ compared with 0 min, all data are means \pm SEM.

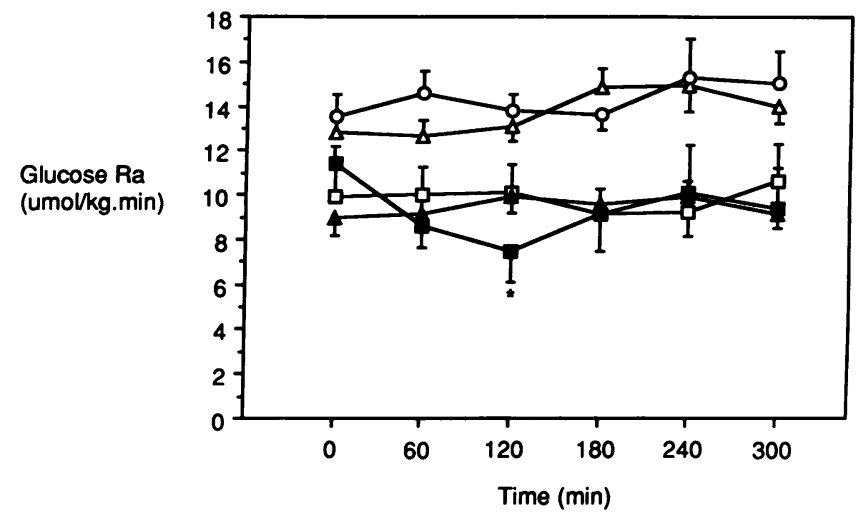

Figure 5. Effect of rhIGF-I $2.0 \mathrm{nmol} / \mathrm{kg} \cdot \mathrm{h}(\Delta)$, rhIGF-I $6.7 \mathrm{nmol} /$ $\mathrm{kg} \cdot \mathrm{h} / \mathrm{kg} \cdot \mathrm{h}(\Delta)$, rhIGF-II $6.7 \mathrm{nmol} / \mathrm{kg} \cdot \mathrm{h}(\mathrm{O})$, insulin $0.17 \mathrm{nmol} / \mathrm{kg} \cdot \mathrm{h}$ $(\boldsymbol{)})$, and normal saline ( $\square$ ) infusion on glucose rate of appearance. $\left({ }^{*}\right)$ $P<0.05$ compared with 0 min, all data are means \pm SEM.

at $120 \mathrm{~min}$ and $300 \mathrm{~min}$ during the IGF-I infusions and at 300 min during the saline infusions (Fig. 3, $a-c$ ). The level of free IGF-I in the normal saline controls was below the limit of sensitivity of the column chromatographic extraction and RIA (40 $\mu \mathrm{g} /$ liter); however, measurable amounts were present after both the rhIGF-I infusions (67 $\pm 4 \mu \mathrm{g} /$ liter and $240 \pm 54 \mu \mathrm{g} /$ liter for the low and high dose infusions, respectively). The patterns of percentage distribution of the protein bound and free forms of IGF-I were almost identical between the low and high dose IGF-I infusions. The infused rhIGF-I appeared to associate preferentially with the $35-60-\mathrm{kD}$ rather than the $150-\mathrm{kD}$ binding proteins.

The plasma insulin levels were below the limit of sensitivity of the RIA used $(0.15 \mu \mathrm{g} / \mathrm{l})$ both before and during normal saline, IGF-I, and IGF-II infusions. Insulin infusion significantly increased the plasma insulin level from $<0.15 \mu \mathrm{g} /$ liter to $0.73 \pm 0.13 \mu \mathrm{g} / \mathrm{liter}$ at $300 \mathrm{~min}$.

\section{Glucose metabolism}

Normal saline. The plasma glucose concentration (Fig. 4), glucose rate of appearance (Fig. 5), and the rate of glucose clearance (Fig. 6) did not alter significantly over the duration of the normal saline infusion.

$r h I G F-I 2.0 \mathrm{nmol} / \mathrm{kg} \cdot \mathrm{h}$. Despite a doubling of the plasma IGF-I level by the end of this infusion and the presence of detectable quantities of free IGF-I in the plasma, no changes in the three parameters of glucose metabolism were observed (Figs. 4-6).

rhIGF-I $6.7 \mathrm{nmol} / \mathrm{kg} \cdot \mathrm{h}$. There was a $41 \%$ reduction $(P$ $<0.01$ ) in the plasma glucose concentration by the end of the high dose IGF-I infusion (Fig. 4), which reflected a 55\% increase $(P<0.01)$ in the rate of glucose clearance (from $3.8 \pm 0.6$ $\mathrm{ml} / \mathrm{kg} \cdot \min$ to $5.9 \mathrm{ml} / \mathrm{kg} \cdot \mathrm{min} ;$ Fig. 6). The rate of glucose appearance was unaltered.

rhIGF-II $6.7 \mathrm{nmol} / \mathrm{kg} \cdot \mathrm{h}$. Glucose clearance increased by $15 \%$ over the course of infusion of this hormone $(P<0.05$, Fig. 6). However, as this effect was associated with a tendency for the $R_{a}$ of glucose to increase (Fig. 5), the plasma glucose concentration was not significantly changed (Fig. 4).

Insulin $0.17 \mathrm{nmol} / \mathrm{kg} \cdot h$. The plasma glucose concentration decreased by $44 \%$ over the duration of this infusion, from $3.6 \pm 0.3 \mathrm{mmol} / \mathrm{liter}$ to $2.0 \pm 0.5 \mathrm{mmol} / \mathrm{liter}(P<0.05$, Fig. 4$)$. 


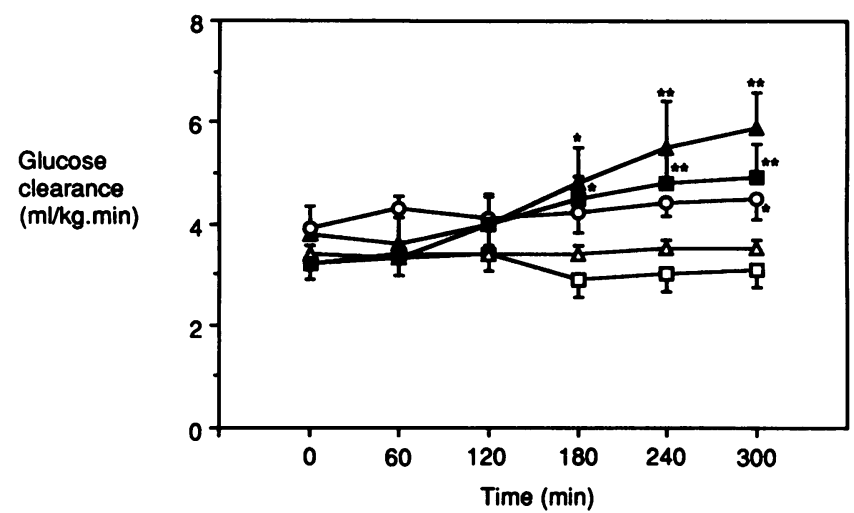

Figure 6. Effect of rhIGF-I $2.0 \mathrm{nmol} / \mathrm{kg} \cdot \mathrm{h}(\Delta)$, rhIGF-I $6.7 \mathrm{nmol} /$ $\mathrm{kg} \cdot \mathrm{h}(\Delta)$, rhIGF-II $6.7 \mathrm{nmol} / \mathrm{kg} \cdot \mathrm{h}(0)$, insulin $0.17 \mathrm{nmol} / \mathrm{kg} \cdot \mathrm{h}(\boldsymbol{(})$, and normal saline $(\square)$ infusion on rate of glucose clearance. $\left({ }^{*}\right) P$ $<0.05,\left(^{* *}\right) P<0.01$ compared with 0 min, all data are means \pm SEM.

There was a transient reduction in the $R_{a}$ of glucose that was maximal at $180 \mathrm{~min}$ (Fig. 5), but a progressive increase in the rate of glucose clearance (Fig. 6).

\section{Plasma electrolytes}

None of the test infusions altered the plasma concentrations of $\mathrm{Na}^{+}, \mathrm{Cl}^{-}$or urea. Over the course of both the high dose rhIGF-I and insulin infusions, the plasma $\mathrm{K}^{+}$concentration was reduced from $3.8 \pm 0.1 \mathrm{mmol} /$ liter to $3.1 \pm 0.1 \mathrm{mmol} / \mathrm{liter}(P$ $<0.01)$ and from $3.9 \pm 0.1 \mathrm{mmol} /$ liter to $3.3 \pm 0.1 \mathrm{mmol} / \mathrm{liter}(P$ $<0.01$ ), respectively.

\section{Protein metabolism}

Normal saline. The $R_{a}$ of urea in one of the animals decreased markedly, and the data from this animal was disregarded, being $>5$ SD beyond the mean. There was a small but consistent reduction in the mean rate of net protein loss of $3 \%(P<0.05)$ over the 300-min normal saline infusion (Fig. 7). The $R_{a}$ of leucine was not altered significantly by the normal saline infusion (Fig. 8), and the protein fractional synthetic rates of the tissues samples are illustrated in Fig. 9, a-e.

$I G F-I 2.0 \mathrm{nmol} / \mathrm{kg} \cdot \mathrm{h}$. The rate of net protein loss (NPL) was reduced from $4.1 \pm 0.4 \mathrm{~g} / \mathrm{kg} \cdot \mathrm{d}$ to $3.5 \pm 0.3 \mathrm{~g} / \mathrm{kg} \cdot \mathrm{d}$ during

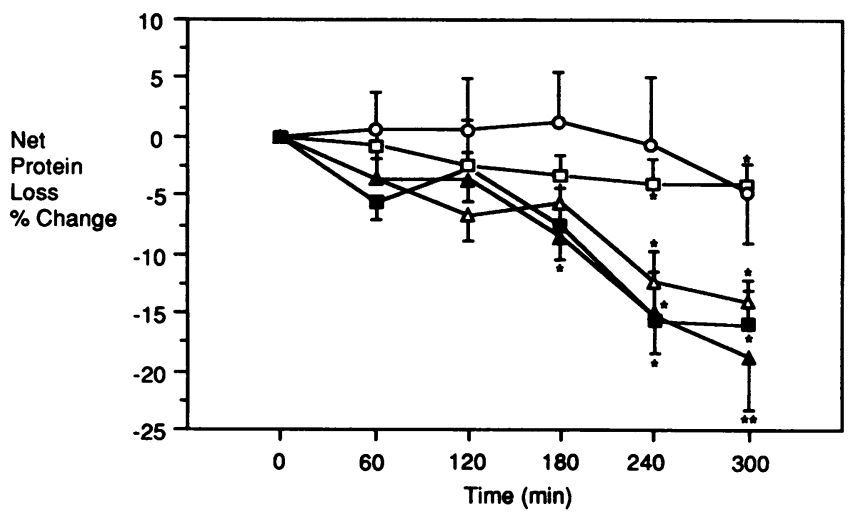

Figure 7. Percentage change of net protein loss during hormone infusion: rhIGF-I $2.0 \mathrm{nmol} / \mathrm{kg} \cdot \mathrm{h}(\Delta)$, rhIGF-I $6.7 \mathrm{nmol} / \mathrm{kg} \cdot \mathrm{h}(\Delta)$, rhIGFII $6.7 \mathrm{nmol} / \mathrm{kg} \cdot \mathrm{h}(0)$, insulin $0.17 \mathrm{nmol} / \mathrm{kg} \cdot \mathrm{h}(\boldsymbol{\theta})$, and normal saline (). $\left({ }^{*}\right) P<0.05,\left({ }^{* *}\right) P<0.01$ compared to $0 \mathrm{~min}$, all data are means \pm SEM.

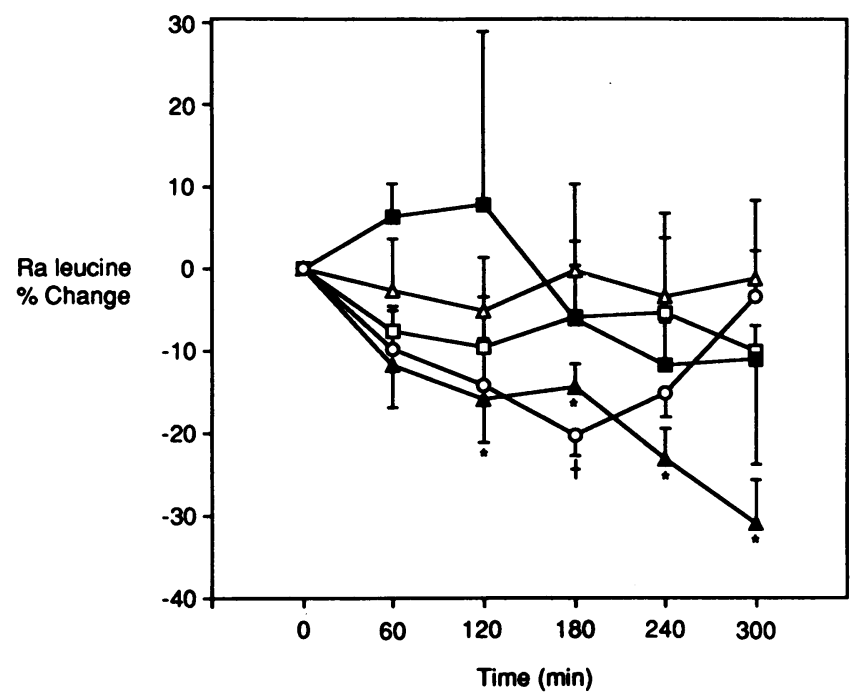

Figure 8. Percentage change of leucine $R_{a}$ during hormone infusion: rhIGF-I $2.0 \mathrm{nmol} / \mathrm{kg} \cdot \mathrm{h}(\Delta)$, rhIGF-I $6.7 \mathrm{nmol} / \mathrm{kg} \cdot \mathrm{h}(\Delta)$, rhIGF-II 6.7 $\mathrm{nmol} / \mathrm{kg} \cdot \mathrm{h}(0)$, insulin $0.17 \mathrm{nmol} / \mathrm{kg} \cdot \mathrm{h}(\boldsymbol{\varpi})$, and normal saline (ם). $\left(^{*}\right)$ $P<0.05,(\dagger) P<0.10$ compared with 0 min all data are means \pm SEM.

the low dose IGF-I infusion $(P<0.05)$. This equates to an $11 \%$ reduction in the rate of net protein loss relative to the normal saline-infused controls. The $R_{a}$ of leucine was not significantly altered by this dose of IGF-I (Fig. 8), and in none of the tissues sampled was the FSR significantly different from those of the normal saline-infused controls (Fig. 9, $a-e$ ).

$I G F-I 6.7 \mathrm{nmol} / \mathrm{kg} \cdot \mathrm{h}$. The rate of net protein loss decreased significantly over the time of the high dose rhIGF-I infusion from $3.5 \pm 0.2 \mathrm{~g} / \mathrm{kg} \cdot \mathrm{d}$ to $2.9 \pm 0.2 \mathrm{~g} / \mathrm{kg} \cdot \mathrm{d}(P<0.005)$, which represents a $15 \%$ reduction in NPL relative to the saline infused controls (Fig. 7). The rate of leucine appearance fell sequentially over the time of the infusion from $5.0 \pm 0.4 \mu \mathrm{mol} / \mathrm{kg} \cdot \mathrm{min}$ to $3.4 \mu \mathrm{mol} / \mathrm{kg} \cdot \min (P<0.01)$ (Fig. 8). The FSR in adductor and psoas muscle were increased $(P<0.05)$. The FSRs in cardiac and diaphragmatic and cardiac muscle were approximately twice that observed in the saline controls $(P<0.01)$ (Fig. 9, $a-d$ ). Similarly, the FSR of liver tissue was significantly higher in the high dose IGF-I infused animals $(P<0.05)$ (Fig. 9 e).

$I G F-I I 6.7 \mathrm{nmol} / \mathrm{kg} \cdot \mathrm{h}$. The rate of NPL was not significantly altered by the infusion of this hormone. There was a tendency for the $R_{a}$ of leucine to decline over the early part of the infusion (Fig. 8). In none of the tissues sampled was the FSR significantly different from those measured in the saline infused controls.

Insulin $0.17 \mathrm{nmol} / \mathrm{kg} \cdot h$. A reduction in NPL from $4.1 \pm 0.4$ $\mathrm{g} / \mathrm{kg} \cdot \mathrm{d}$ to $3.5 \pm 0.3 \mathrm{~g} / \mathrm{kg} \cdot \mathrm{d}(P<0.05)$ was observed during the insulin infusion, representing a $12 \%$ reduction relative to the normal saline-infused controls. The leucine $R_{a}$ was not significantly altered $(4.6 \pm 0.2 \mu \mathrm{mol} / \mathrm{kg} \cdot \mathrm{min}$ to $4.0 \pm 0.5 \mu \mathrm{mol} /$ $\mathrm{kg} \cdot \mathrm{min}$ ), and in none of the tissues sampled was the FSR different from the control values.

\section{Discussion}

In this study, isotopic tracer methodology was used to investigate the metabolic effects of short-term infusions of rhIGF-I and -II in fasted lambs. These effects were compared with those 


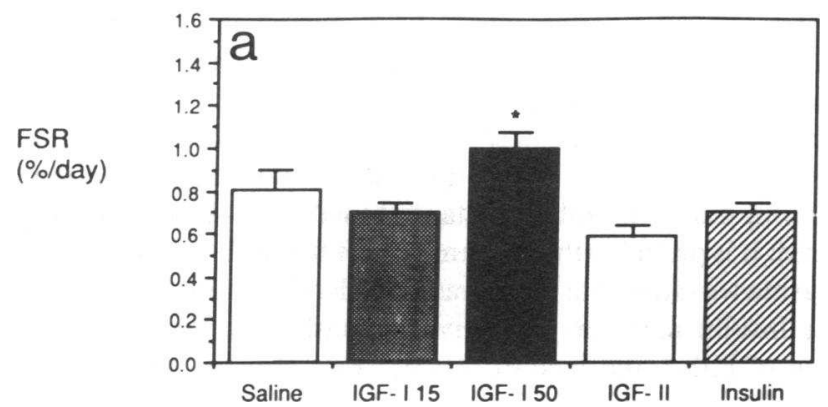

Psoas
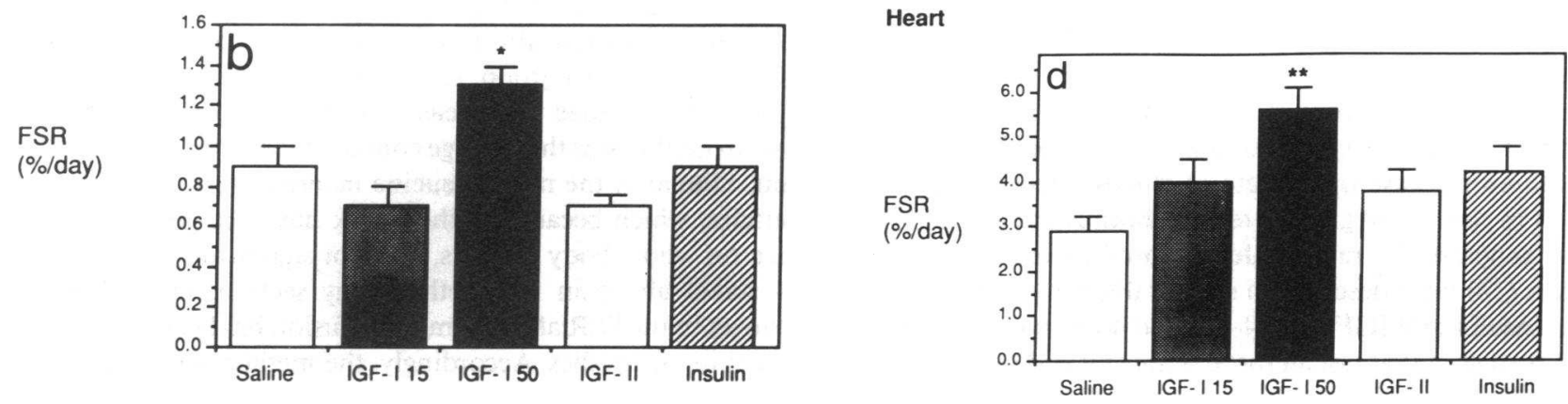

Diaphragm

Liver
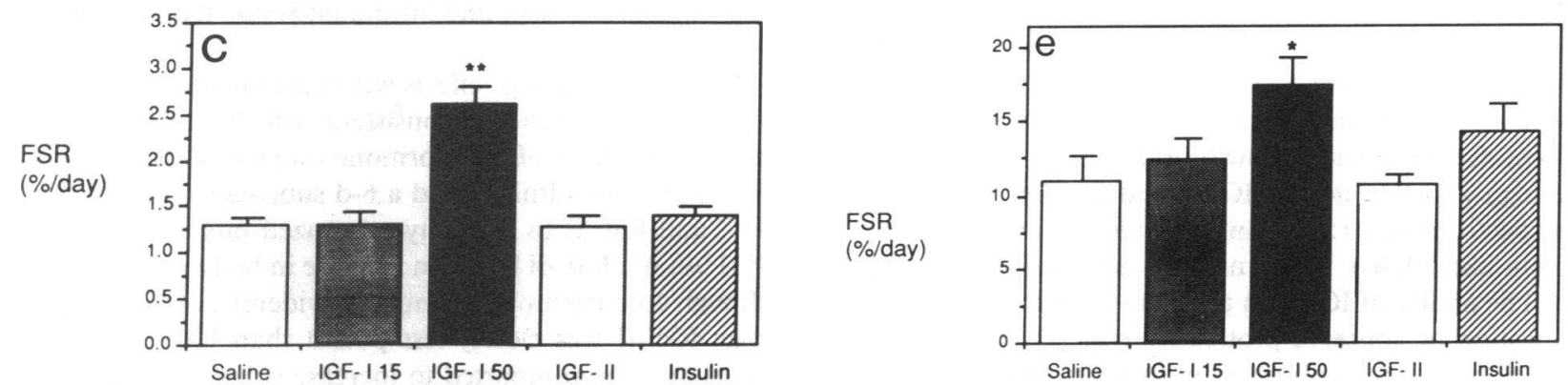

Figure 9. (a-e) FSR of protein synthesis in skeletal and cardiac muscle and liver tissue. $\left(^{*}\right) P<0.05$, $\left(^{* *}\right) P<0.01$ compared with normal saline-infused controls, all data are means \pm SEM. IGF-1 15 represents $15 \mu \mathrm{g} / \mathrm{kg} \cdot \mathrm{h}(2 \mathrm{nmol} / \mathrm{kg} \cdot \mathrm{h}) ; \mathrm{IGF}-150 \mathrm{indicates} 6.7 \mathrm{nmol} / \mathrm{kg} \cdot \mathrm{h}$.

of an insulin infusion of the same hypoglycemic potential as the rhIGF-I infusion. The metabolic response to a lower dose of rhIGF-I that did not induce hypoglycemia was also investigated. We observed that rhIGF-I is more potent than rhIGF-II in increasing the rate of peripheral glucose clearance and less potent than insulin (with an rhIGF-I/insulin dose ratio of 40:1 having the same hypoglycemic effect). The rhIGF-I and insulin infusions reduced the rate of net protein loss to a similar extent, although only the high dose rhIGF-I infusion clearly stimulated protein synthesis in all of the tissues sampled. At lower doses of rhIGF-I infusion, protein metabolism was altered in the absence of any effect on carbohydrate metabolism. The rhIGF-II infusion did not reduce the rate of net protein loss or stimulate protein synthesis.
In the physiological state, $<1 \%$ of the total plasma IGF-I is not associated with binding proteins $(19,20)$, and although the amount of free IGF-II has not been measured, it is likely that only negligible amounts are present under normal conditions given the relatively greater affinity of human (4), ovine (21), and rat (40) binding proteins for IGF-II relative to IGF-I. The hypoglycemic action of the IGFs has been attributed to the presence of free hormone in the plasma (7) as protein-bound IGF-I may be prevented from interacting with the insulin receptor. When large amounts of exogenous IGF are infused rapidly, the capacity of the binding proteins may be exceeded, allowing unbound IGF in the plasma. At the end of both the low and high dose rhIGF-I infusions $10 \%$ of the total plasma IGF-I was in the free form, but in absolute quantities there were 
almost four times more free IGF-I after the high dose infusion (Fig. 3, $b$ and $c$ ). Only the high dose infusion effected an increase in the rate of peripheral glucose clearance (Fig. 6). It would appear reasonable to conclude that a threshold level of free IGF-I in the plasma must be exceeded before a measurable increase in glucose clearance occurs, although in our studies we have not directly distinguished differences in the roles of free and protein-bound IGF-I. rhIGF-II also significantly accelerated the rate of glucose clearance, but the magnitude of this increase was less than one-third as great as that of the same dose of rhIGF-I. Although not measured directly, we infer from this result that there was a significant amount of free IGF-II present in the plasma and that this was responsible for the increase in glucose clearance. The apparently less potent hypoglycemic action of the IGF-II may reflect the greater affinity of IGF-II for the plasma binding proteins and consequently reduced amount of free IGF-II present. Alternatively, free IGF-II may be cleared more rapidly than free IGF-I.

The actions of the high dose rhIGF-I and rhIGF-II infusions on glucose metabolism could be distinguished from those of insulin. Whereas the hypoglycemic action of insulin resulted from both an increase in the rate of glucose clearance and a reduction in the rate of glucose release, both IGF-I and IGF-II failed to suppress the rate of glucose production. Jacob and colleagues (14) have described a similar disparity in responses between insulin and IGF-I in 24-h fasted adult rats. These observations suggest that not all the actions of IGF-I on carbohydrate metabolism can be ascribed to actions on the insulin receptor. The issue of whether the effects of IGF-I on carbohydrate metabolism are mediated via the insulin receptor has been controversial (18). Our data favor at least some independent effects. The differential effect of the hormones on carbohydrate metabolism may reflect a greater sensitivity of hepatic tissues to the hypoglycemic actions of insulin and would be consistent with the relative paucity of IGF receptors on liver cells except during times of growth (41).

The high and low dose rhIGF-I and insulin infusion resulted respectively in a 15,11 , and $12 \%$ reduction in the rate of net protein loss relative to the normal saline infused controls (Fig. 7). The ability of IGF-I to promote growth after chronic administration or conserve protein over the course of shortterm infusions has been observed in hypophysectomized (11) and diabetic rats (13), but there are few in vivo data clarifying whether the anabolic actions of this hormone represent a reduction in catabolism, a stimulation of protein synthesis, or a combination of both. In our animals that received the high dose rhIGF-I infusion, the rate of leucine flux was significantly lowered, implying that the rate of whole body protein catabolism is reduced by IGF-I. As the rate of ${ }^{14} \mathrm{C}$-labeled leucine incorporation into the five tissues sampled was elevated, we conclude that the protein-conserving effects of IGF-I result from both a reduction of catabolism and an acceleration of protein synthesis. However, in interpreting these data it must be remembered that we have measured only the effects of short-term infusions of rhIGF-I, and that the observed changes in protein kinetics would not necessarily be sustained if the infusions were to be maintained for longer periods.

Our observations contrast with those of Jacob and coworkers (14) who have reported that in normal adult rats a high dose IGF-I infusion of short duration reduced the rate of protein degradation without accelerating the rate of synthesis.
Rather, infusion of IGF-I reduced the rate of leucine uptake by muscle and liver tissue and the effects of IGF-I on protein kinetics observed in that study were almost indistinguishable from those of insulin. There exist several differences between our study and that of Jacob and co-workers that may account for the disparity in the observed effects on protein synthesis. In the latter study, IGF-I was infused at a rate five times faster than in our own and a substantial loading dose was administered. It is probable that the amount of free IGF-I present in the plasma was such that there was considerable crossreaction with the insulin receptors, conceivably masking differences of action of IGF-I and insulin. There exists also the possibility of differences in response between adult rats used in their study and growing lambs used in the present study; for example, hepatocytes appear to lose their IGF-I receptors with maturity (41).

The mechanism of the protein conservation seen in the low dose rhIGF-I and insulin-infused animals is less clear than in the high dose IGF-I group. Although in both groups the mean $R_{a}$ of leucine tended to decrease over the duration of the infusion, in neither was this change consistent or statistically significant. Similarly, the rate of leucine incorporation into skeletal muscles, which because of their bulk have the greatest influence on whole body kinetics, was not significantly increased. As stated above in the methodology section, the extent of changes in the FSR after hormone infusion has been underestimated in our studies. Accordingly, the methodology used may have failed to detect a small increase in FSR after the low dose rhIGF-I or insulin infusions. Nevertheless, given the magnitude of the effect on FSR and leucine $R_{a}$ of the high dose rhIGF-I infusion, it is clear that there are important differences in the effects of rhIGF-I and insulin infusion on protein metabolism.

No protein anabolic effects were attributable to the rhIGFII infusions: this result is consistent with the limited in vivo data on the effects of this hormone on growth. Schoenle and co-workers (16) administered a 6-d subcutaneous infusion of IGF-I and IGF-II to hypophysectomized rats and found that IGF-I but not IGF-II led to an increase in body weight and that although both hormones stimulated widening of the costal cartilage, IGF-II was clearly less potent than IGF-I. Both hormones have been reported to increase collagen synthesis and reduce collagen degradation in rat calvarial cultures, but IGF-I was approximately three times more potent than IGF-II (17). The protein anabolic potential, if any, of infused rhIGF-II is likely to be counteracted by the resultant lowering plasma of IGF-I levels that has been observed by us (Fig. 2) and by others in rats transplanted with IGF-II secreting tumors (42).

During the infusion of rhIGF-I, most associated with the $35-60-\mathrm{kD}$ binding protein fractions and there was no signifcant increase in the $150-\mathrm{kD}$ bound form. In contrast, after growth hormone administration the increase in circulating IGF-I is associated with both fractions and particularly with the $150-\mathrm{kD}$ form (43). As the pattern of distribution of IGF-I across IGF binding proteins is different in response to growth hormone administration than during rhIGF-I infusion, it is reasonable to anticipate that there will be differences in the metabolic effects of the raised plasma IGF-I levels in these two circumstances. While the function of the differing circulating forms of IGF-I has been a subject of speculation (44), no firm conclusions can be drawn from the available data. As free IGF- 
I does not rise substantially after growth hormone administration in sheep but remains $<2 \mu \mathrm{g} /$ liter (Hodgkinson, S. C., J. J. Bass, and P. D. Gluckman, personal communication), it would appear most likely that IGF-I in the $35-60-\mathrm{kD}$ fraction is responsible for the anabolic actions we observed. This size range includes at least three potential forms of IGF-I: that associated with BP-1, BP-2, and BP-3 not complexed into the $150-\mathrm{kD}$ form. It has recently been established that IGFBP-1 is able to cross intact vascular barriers in the rat heart (45), which suggests that the binding proteins may have an active role in influencing the actions of IGF-I within the tissues.

In summary, we have observed that infused rhIGF-I can reduce plasma glucose by increasing glucose clearance and conserve protein by both encouraging protein synthesis in various tissue and by reducing protein metabolism. These observations support the postulation of $O$ 'Sullivan and colleagues (15) that circulating IGF-I plays a role as a regulator of protein metabolism in the fasted state. The metabolic effects of rhIGF-I could be distinguished from those of an insulin infusion of equal hypoglycemic activity: the insulin infusion reduced the rate of glucose production whereas rhIGF-I did not, and insulin did not accelerate tissue protein synthesis. These observations suggest that at least some of the metabolic effects of circulating IGF-I are mediated by receptors other than those for insulin. As a low dose rhIGF-I infusion was able to reduce net protein loss without influencing glucose kinetics, we infer that protein metabolism is more sensitive than carbohydrate metabolism to circulating rhIGF-I. The protein-sparing effect of rhIGF-I did not appear to be shared by rhIGF-II infusion of the dose investigated.

The anabolic effects of rhIGF-I may have therapeutic potential for severely septic or multiply injured surgical patients with a high rate of protein catabolism. In particular, stimulation of protein synthesis in cardiac and diaphragmatic muscle by exogenous rhIGF-I, combined with a putative positive inotropic action of this hormone (46), may be useful in the treatment of sepsis-related cardiopulmonary failure.

\section{References}

1. Blundell, T. L., S. Bedarkar, E. Rinderknecht, and R. E. Humbel. 1979. Insulin-like growth factors: a model for tertiary structure accounting for immunoreactivity and receptor binding. Proc. Natl. Acad. Sci. USA. 75:180-184.

2. Zapf, J., C. H. Schmid, and E. R. Froesch. 1984. Biological and immunological properties of insulin-like growth factors I and II. Clin. Endocrinol. Metab. 13:3-30.

3. Barreca, A., and F. Minuto. 1989. Somatomedins: chemical and functional characteristics of the different molecular forms. J. Clin. Endocrinol. Metab. 12:279-293

4. Zapf, J., E. Schoenle, and E. R. Froesch. 1978. Insulin-like growth factors I and II: some biological actions and receptor binding characteristics of two purified constituents of non-suppressible insulin-like activity of human serum. Eur. J. Biochem. 87:285-296.

5. Bolinder, J., A. Lindblad, P. Engfeldt, and P. Arner. 1987. Studies of acute effects of insulin-like growth factors I and II in human fat cells. J. Clin. Endocrinol. Metab. 65:732-737.

6. Poggi, C., Y. Le Marchand-Brustel, J. Zapf, E. R. Froesch, and P. Freychet. 1979. Effects and binding of insulin-like growth factor $I$ in the isolated soleus muscle of lean and obese mice: comparison with insulin. Endocrinology. 105:723-730.

7. Zapf, J., C. Hauri, M. Waldvogel, and E. R. Froesch. 1986. Acute metabolic effects and half-lives of intravenously administered insulinlike growth factors and II in normal and hypophysectomized rats. J. Clin. Invest. 77:1768-1775.

8. Guler, H.-P., J. Zapf, and F. R. Froesch. 1987. Short-term metabolic effects of recombinant human insulin-like growth factor $I$ in healthy adults. $N$. Engl. $J$. Med. 317:137-140.
9. Froesch, E. R., and J. Zapf. 1985. Insulin-like growth factors and insulin: comparative aspects. Diabetologia. 28:485-493.

10. Roeder, R. A., K. L. Hossner, R. G. Sasser, and J. M. Gunn. 1988. Regulation of protein turnover by recombinant human insulin-like growth factor-1 in L6 myotube cultures. Horm. Metab. Res. 20:699-700.

11. Schoenle, E., J. Zapf, R. E. Humbrel, and E. R. Froesch. 1982. Insulin-like growth factor 1 stimulates growth in hypophysectomized rats. Nature (Lond.). 296:252-253.

12. Guler, H.-P., J. Zapf, E. Scheiwiller, and E. R. Froesch. 1988. Recombinant human insulin-like growth factor I stimulates growth and has distinct effects on organ size in hypophysectomized rats. Proc. Natl. Acad. Sci. USA. 85:48894893.

13. Scheiwiller, E., H.-P. Guler, J. Merryweather, C. Scandella, W. Maerki, J. Zapf, and E. R. Froesch. 1986. Growth restoration of insulin-deficient diabetic rats by recombinant human insulin-like growth factor I. Nature (Lond.). 323:169-171

14. Jacob, R., E. Barrett, G. Plewe, K. D. Fagin, and R. S. Sherwin. 1989. Acute effects of insulin-like growth factor 1 on glucose and amino acid metabolism in the awake fasted rat. J. Clin. Invest. 83:1717-1723.

15. O'Sullivan, U., P. D. Gluckman, B. H. Breier, S. Woodall, R. A. Siddiqui, and S. N. McCutcheon. 1989. Insulin-like growth factor-I (IGF-I) in mice reduces weight loss during starvation. Endocrinology. 125:2793-2795.

16. Schoenle, E., J. Zapf, C. Hauri, T. Steiner, and E. R. Froesch. 1985 Comparison of in vivo effects of insulin-like growth factors I and II and of growth hormone in hypophysectomized rats. Acta Endocrinol. 108:167-174.

17. McCarthy, T. L., M. Centrella, and E. Canalis. 1989. Regulatory effects of insulin-like growth factors I and II on bone collagen synthesis in rat calvarial cultures. Endocrinology. 124:301-309.

18. King, G. L., C. R. Kahn, M. M. Rechler, and S. P. Nissley. 1980. Direct demonstration of separate receptors for growth and metabolic activities of insulin and multiplication-stimulating activity (an insulinlike growth factor) using antibodies to the insulin receptor. J. Clin. Invest. 66:130-140.

19. Martin, J. L., R. C. Baxter. 1986. Insulin-like growth factor-binding protein from human plasma. Purification and characterization. J. Biol. Chem. 261:8754-8757.

20. Daughaday, W. H., A. P. Ward, A. C. Goldberg, B. Trevedi, and M. Kapadia. 1982. Characterization of somatomedin binding in human serum by ultracentrifugation and gel filtration. J. Clin. Endocrinol. Metab. 55:916-921.

21. Hodgkinson, S. C., S. R. Davis, D. D. Burleigh, H. V. Henderson, and P. D. Gluckman. 1987. Metabolic clearance of protein bound free insulin-like growth factor-I in fed and starved sheep. J. Endocrinol. 115:223-240.

22. Davenport, M. L., D. R. Clemmons, M. V. Miles, C. Camacho-Hubner, A. J. D'Ercole, and L. E. Underwood. 1990. Regulation of serum insulin-like growth factor-I (IGF-I) and IGF binding proteins during pregnancy. Endocrinology. 127:1278-1286.

23. Meuli, C., J. Zapf, and E. R. Froesch. 1978. NSILA-carrier protein abolishes the action of nonsuppressible insulin-like activity (NSILA-S) on perfused rat heart. Diabetologia. 14:253-259.

24. Blum, W. F., E. W. Jenne, F. Reppin, K. Kietzmann, M. B. Ranke, and J. R. Bierich. 1989. Insulin-like growth factor I (IGF-I)-binding protein complex is a better mitogen than free IGF-I. Endocrinology. 125:766-772.

25. Elgin, R. G., W. H. Busby, Jr., and D. R. Clemmons. 1987. An insulin-like growth factor (IGF) binding protein enhances the biologic response to IGF-I. Proc. Natl. Acad. Sci. USA. 84:3254-3258.

26. Ponting, G. A., D. Halliday, J. D. Teale, and A. J. W. Sim. 1988. Postoperative positive nitrogen balance with intravenous hyponutrition and growth hormone. Lancet. i:438-440.

27. Ziegler, T. R., L. S. Young, J. McK. Manson, and D. W. Wilmore. 1988. Metabolic effects of recombinant human growth hormone in patients receiving parenteral nutrition. Ann. Surg. 208:6-16.

28. Douglas, R. G., D. A. Humberstone, A. Haystead, and J. H. F. Shaw. 1990. The metabolic effects of recombinant human growth hormone: isotopic studies in the postabsorptive state and during total parenteral nutrition. $\mathrm{Br}$. J. Surg. 77:785-790.

29. Dahn, M. S., M. P. Lange, and L. A. Jacobs. 1988. Insulinlike growth factor 1 production in inhibited in human sepsis. Arch. Surg. 123:1409-1414.

30. Douglas, R. G., B. H. Breier, K. T. Ball, J. H. F. Shaw, and P. D. Gluckman. 1990. Metabolic effects of insulin-like growth factor I (IGF-I) infusion in lambs. The Endocrine Society 72nd Annual Meeting, Atlanta, Georgia. (Abstr.)

31. Wolfe, R. R. 1984. Tracers in Metabolic Research: Radio-isotopes and Stable Isotopes and Mass Spectometry Methods. A. R. Liss, New York. 287 pp.

32. Nissen, S. L., C. Van Huysen, and M. Haymond. 1982. Measurement of branched chain amino acids and branched chain keto acids in plasma by high pressure liquid chromatography. J. Chromatogr. 232:170-175.

33. Wolfe, R. R., and J. H. F. Shaw. 1985. Glucose and FFA kinetics in sepsis role of glucagon and sympathetic nervous system activity. Am. J. Physiol. 248:E236-E243.

34. Breier, B. H., B. W. Gallaher, and P. D. Gluckman. 1991. Radioimmuno- 
assay for insulin-like growth factor I: solutions to some potential problems and pitfalls. J. Endocrinol. 128:347-357.

35. Butler, J. H., and P. D. Gluckman. 1986. Circulating insulin-like growth factor binding proteins in fetal, neonatal and adult sheep. J. Endocrinol. 109:333338.

36. Hodgkinson, S. C., L. Moore, J. R. Napier, S. R. Davis, J. J. Bass, and P. D. Gluckman. 1989. Characterisation of insulin-like growth factor binding proteins in ovine tissue fluids. J. Endocrinol. 120:429-438.

37. Bassett, N. S., B. H. Breier, S. C. Hodgkinson, S. R. Davis, H. V. Henderson, and P. D. Gluckman. 1990. Plasma clearance of radiolabelled IGF-I in the late gestation ovine fetus. J. Develop. Physiol. (Eynsham). 14:73-79.

38. Steele, R. 1959. Influences of glucose loading and injected insulin on hepatic glucose output. Ann. NY Acad. Sci. 82:420-430.

39. Davis, S. R., T. N. Barry, and G. A. Hughson. 1981. Protein synthesis in tissues of growing lambs. Br. J. Nutr. 46:409-419.

40. Rechler, M. M., J. Zapf, S. P. Nissley, E. R. Froesch, A. C. Moses, J. M Podskalny, E. F. Schilling, and R. E. Humbel. 1980. Interactions of insulin-like growth factors I and II and multiplication-stimulating activity with receptors and serum carrier proteins. Endocrinology. 107:1451-1459.

41. Caro, J. F., J. Poulos, O. Ittoop, W. J. Pories, E. G. Flinkinger, and M. K. Sinha. 1988. Insulin-like growth factor I binding in hepatocytes from human liver, human hepatoma, and normal, regenerating, and fetal rat liver. J. Clin. Invest. 81:976-981.

42. Wilson, D. M., S. N. Perkins, J. A. Thomas, S. Seelig, S. A. Berry, T. E. Hamm, Jr, A. R. Hoffman, R. L. Hintz, and R. G. Rosenfeld. 1989. Effects of elevated serum insulinlike growth factor-II on growth hormone and insulinlike growth factor-I mRNA and secretion. Metabolism. 38:57-62.

43. Davis, S. R., P. D. Gluckman, S. C. Hodgkinson, V. C. Farr, B. H. Breier, and B. D. Burleigh. 1989. Comparison of the effects of administration of recombinant bovine growth hormone or M-Met insulin-like growth factor-I to lactating goats. J. Endocrinol. 123:33-39.

44. Gluckman, P. D., B. H. Breier, N. S. Bassett, S. R. Davis, and S. Hodgkinson. 1989. Insulin-like growth factor binding in the ruminant ruminant. In Insulin-like Growth Factor Binding Proteins. S. L. S. Drop and R. L. Hintz, editors. Elsevier Science Publishers, Amsterdam. 159-168.

45. Bar, R. S., D. R. Clemmons, M. Boes, W. H. Busby, B. A. Booth, B. L Dake, and A. Sandra. 1990. Transcapillary permeability and subendothelial distribution of endothelial and amniotic fluid insulin-like growth factor binding proteins in the rat heart. Endocrinology. 127:1078-1086.

46. Vetter, U., C. Kupferschmid, D. Lang, and S. Pentz. 1988. Insulin-like growth factors and insulin increase the contractility of neonatal rat cardiocytes in vitro. Basic Res. Cardiol. 83:647-654. 